\title{
Multiple Roles of Connexins in Atherosclerosis- and Restenosis-Induced Vascular Remodelling
}

\author{
Sandrine Morel \\ Department of Pathology and Immunology, Faculty of Medicine, University of Geneva, Geneva, Switzerland
}

\section{Key Words}

Atherosclerosis · Restenosis · Vascular remodelling •

Connexins

\begin{abstract}
Endothelial dysfunction is the initial step in atherosclerotic plaque development in large- and medium-sized arteries. This progressive disease, which starts during childhood, is characterized by the accumulation of lipids, macrophages, neutrophils, T lymphocytes and smooth muscle cells in the intima of the vessels. Erosion and rupture of the atherosclerotic plaque may induce myocardial infarction and cerebrovascular accidents, which are responsible for a large percentage of sudden deaths. The most common treatment for atherosclerosis is angioplasty and stent implantation, but these surgical interventions favour a vascular reaction called restenosis and the associated de-endothelialization increases the risk of thrombosis. This review provides an overview of the role of connexins, a large family of transmembrane proteins, in vascular remodelling associated with atherosclerosis and restenosis. The connexins expressed in the vascular wall are Cx37, Cx40, Cx43 and Cx45; their expressions vary with vascular territory and species. Connexins form hemichannels or gap junction channels, allowing the exchange of ions and
\end{abstract}

small metabolites between the cytosol and extracellular space or between neighbouring cells, respectively. Connexins have important roles in vascular physiology; they support radial and longitudinal cell-to-cell communication in the vascular wall, and significant changes in their expression patterns have been described during atherosclerosis and restenosis.

(c) 2014 S. Karger AG, Basel

\section{Introduction}

Atherosclerosis is a progressive inflammatory disease of large- and medium-sized arteries whose fatal complications comprise myocardial infarction or stroke $[1,2]$. The complications of this pathology are observed in the adult population, but the disease starts already during adolescence and implicates multiple cell types such as endothelial cells (ECs), inflammatory cells and smooth muscle cells (SMCs). The roles of these cells in the formation and progression of atherosclerotic plaque are the subject of many excellent reviews [3-7]. Atherosclerotic disease is usually treated by angioplasty and stenting, but clinical studies have shown that the treatment efficacy may be reduced by early and late thrombosis or restenosis at the site

\section{KARGER}

E-Mail karger@karger.com

www.karger.com/jvr
(C) 2014 S. Karger AG, Basel

$1018-1172 / 14 / 0512-0149 \$ 39.50 / 0$
Dr. Sandrine Morel

Department of Pathology and Immunology, Faculty of Medicine

University of Geneva, CMU, Rue Michel-Servet 1

$\mathrm{CH}-1211$ Geneva 4 (Switzerland)

E-Mail sandrine.morel@unige.ch 
Table 1. Cx nomenclature

\begin{tabular}{ll}
\hline Cx nomenclature & Cx nomenclature based \\
based on the gene sequence & on the predicted molecular mass \\
\hline GJA1 & Cx43 \\
GJA3 & Cx46 \\
GJA4 & Cx37 \\
GJA5 & Cx40 \\
GJA6 & Cx33 (only in mice) \\
GJA8 & Cx50 \\
GJA9 & Cx59 (only in humans) \\
GJA10 & Cx57 (mice)/Cx62 (humans) \\
GJB1 & Cx32 \\
GJB2 & Cx26 \\
GJB3 & Cx31 \\
GJB4 & CX30.3 \\
GJB5 & Cx31.1 \\
GJB6 & Cx30 \\
GJB7 & Cx25 (only in humans) \\
GJC1 & Cx45 \\
GJC2 & Cx47 \\
GJC3 & Cx29 (mice)/Cx30.2 (humans) \\
GJD2 & Cx36 \\
GJD3 & Cx30.2 (mice)/Cx31.9 (humans) \\
GJD4 & Cx39 (mice)/Cx40.1 (humans) \\
GJE1 & Cx23 \\
\hline
\end{tabular}

Cx genes are named according to their sequence: $\alpha$ (GJA), $\beta$ (GJB), $\gamma$ (GJC), $\delta$ (GJD) and $\varepsilon$ (GJE), and they receive a number in the order of their discovery. Cx proteins are named according to their predicted molecular mass.

of the intervention [8]. Many investigations are currently focussing on the role of interactions and information exchange between cells during the processes of atherosclerosis, thrombosis and restenosis. In this review, I will focus on the role of intercellular communication provided by connexin $(\mathrm{Cx})$ proteins during vascular remodelling associated with atherogenesis and restenosis.

\section{Cx Channels}

Cx are members of a family of 20 proteins in mice and 21 proteins in humans. Cx genes consist of a $5^{\prime}$-untranslated exon, an intron of variable length, an exon harbouring the complete coding region and a $3^{\prime}$-untranslated exon [9]. $\mathrm{Cx}$ genes are named according to their sequence: $\alpha$ (GJA), $\beta$ (GJB), $\gamma$ (GJC), $\delta$ (GJD) and $\varepsilon$ (GJE), and they receive a number in the order of their discovery $[10,11]$ (table 1). Cx proteins are synthesized in the endoplasmic reticulum, where they form hexameric connexons (an asso- ciation of $6 \mathrm{Cx}$ ). This process is completed in the Golgi apparatus, after which connexons traffic to the plasma membrane along microtubules [12-14]. The turnover of $\mathrm{Cx}$ proteins is relatively fast; their half-lives range from 1 to $5 \mathrm{~h}$ [15]. Cx proteins exhibit $4 \mathrm{a}$-helical transmembrane domains (M1 to M4), 2 extracellular loops (EL1 and EL2) linked by 2 disulphide bonds, a short cytoplasmic loop (CL) and cytoplasmic $\mathrm{NH}_{2}$ and $\mathrm{COOH}$ termini (NT and $\mathrm{CT}$, respectively) (fig. 1a). The most variable part of $\mathrm{Cx}$ proteins is the $\mathrm{CT}$, which allows interactions with other proteins such as kinases or structural proteins. In addition, the $\mathrm{CT}$ is involved in the modulation of channel activity in response to appropriate biochemical stimuli [16-19]. The highly conserved EL1 and EL2 are involved in the docking and recognition of compatible $\mathrm{Cx}$ [12]. Cx proteins are named according to their molecular mass deduced from their cDNA sequences (table 1). As mentioned above, $6 \mathrm{Cx}$ oligomerize to form connexons (fig. 1a). This hemichannel can be composed of 6 identical Cx (homomeric connexon) or multiple $\mathrm{Cx}$ types (heteromeric connexon). Non-covalent interactions between the extracellular loops of 2 connexons from 2 neighbouring cells allow the formation of gap junction (GJ) channels (fig. 1a). These channels are composed of identical or different connexons and are thus described as homotypic or heterotypic channels, respectively. Hemichannels and GJ channels allow the passage of ions and small molecules $(\sim 1,000 \mathrm{Da})$ between the cytoplasm and the extracellular space or between the cytosol of 2 neighbouring cells, respectively. Cellular effects of GJ channels, hemichannels and Cx (channel-independent effects) are described in several organs such as the heart, brain, kidney, liver, lens, ear, ovary, bone or testis (fig. 1b).

Exchanges via GJ channels involve ions, small metabolites, second messengers, small linear peptides or small silencing RNA [15, 20-22]. Usually, GJ channels are open to facilitate communication between the cells. Their closure is regulated by modification of the intra-cellular $\mathrm{Ca}^{2+}$ concentration, $\mathrm{pH}$ and transmembrane voltage and by phosphorylation/dephosphorylation of the CT. GJ intercellular communication is crucial for fast coordinated activities such as contraction of the heart or the transmission of neuronal signals at electrical synapses, but it is also involved in slower physiological processes such as cell growth, differentiation, development and proliferation. In addition, the contribution of GJ channels to cell death has been linked to the exchange of $\mathrm{Ca}^{2+}$, inositol 1.4.5-triphosphate (IP3), cAMP and cGMP through these channels, whereas their contribution to cell survival has been associated with the exchange of ATP, glucose, ascorbic acid or glutathione [23]. 


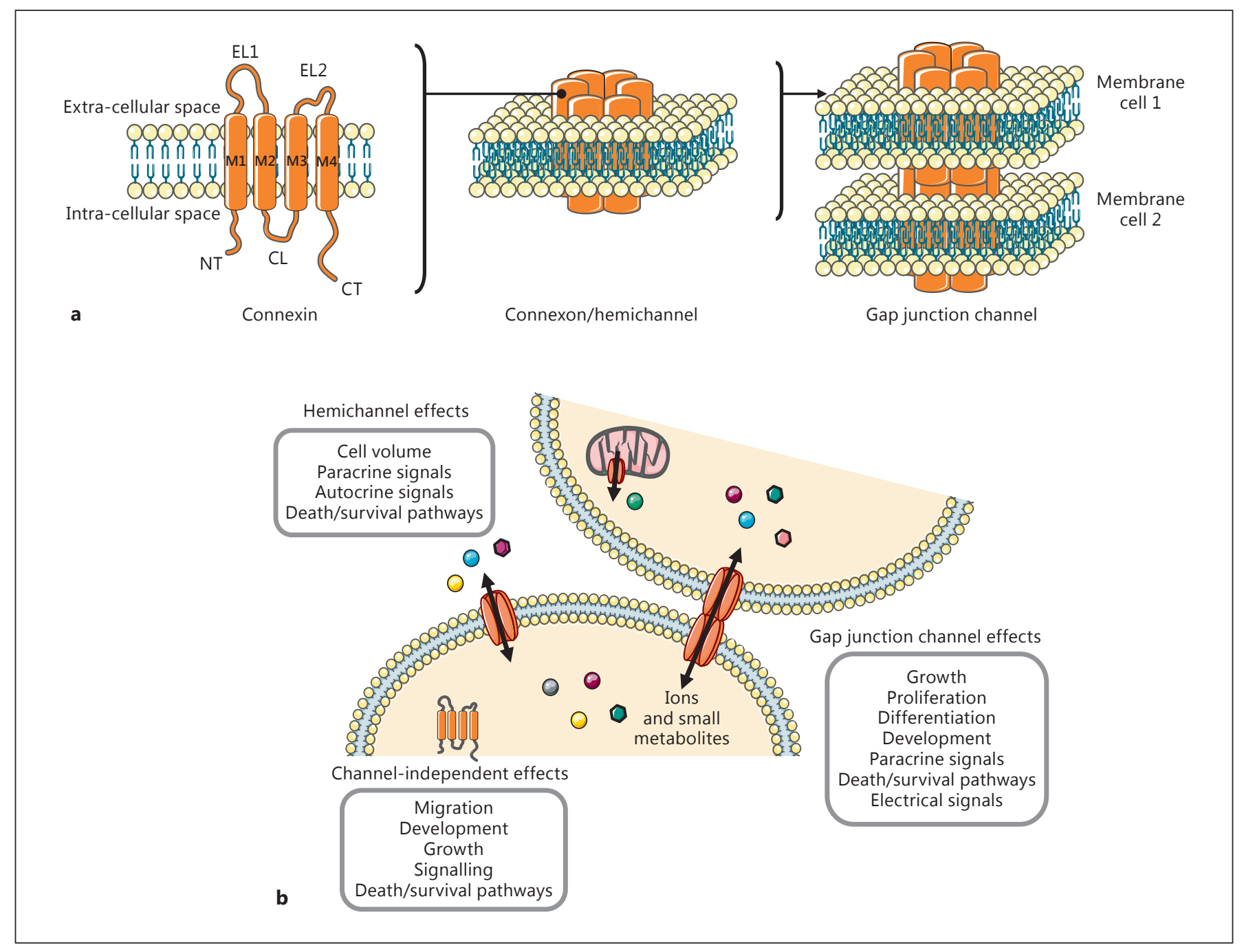

Fig. 1. Schematic representation of Cx channels. a Cx have 4 transmembrane domains (M1, M2, M3 and M4), 2 extracellular loops (EL1 and EL2), a cytoplasmic loop (CL) and cytoplasmic $\mathrm{NH}_{2}-$ and $\mathrm{COOH}$-termini (NT and $\mathrm{CT}$, respectively). Connexons or hemichannels are formed by the association of $6 \mathrm{Cx}$, and the docking of 2 connexons from neighbouring cells forms GJ channels. b Cx proteins participate in the regulation of important cellular processes via channel-dependent and channel-independent effects.

In contrast to GJ channels, connexons are in a closed configuration under physiological conditions. Their opening can be induced by different stimuli such as the removal of extracellular calcium, dephosphorylation, hypoxic or ischemic stress and mechanical stimulation [24-26]. Hemichannels are implicated in the maintenance of cell homeostasis, paracrine or autocrine signalling and the activation of survival pathways. Compounds that can be released by hemichannels include ions and small molecules such as ATP, glutamate, prostaglandin E2 or nicotinamide adenine dinucleotide $\left(\mathrm{NAD}^{+}\right)[27$,
28]. ATP released by hemichannels can bind to purinergic receptors and participates in several cellular processes depending on the implicated $\mathrm{Cx}$ and the organ. For example: (1) ATP release by Cx37 hemichannels limits monocyte adhesion and thereby prevents atherosclerotic plaque development [29], (2) the Cx26 and Cx30 hemichannels are described to play a crucial role in inner ear calcium signalling by promoting ATP release [30] and (3) in ECs ATP release by $\mathrm{Cx} 43$ hemichannels has been proposed to play a role in the initiation of early innate immune responses following activation by peptidoglycan 
derived from Staphylococcus epidermidis [31]. Glutamate has been described to be secreted by $\mathrm{Cx} 43$ hemichannels in astrocytes after the removal of divalent cations [32] and by $\mathrm{Cx} 26$ hemichannels in horizontal cells from the retina [33]. Glutamate release in pathological situations leads to overstimulation of post-synaptic glutamate receptors and neuronal death [34]. Prostaglandin E2 release by $\mathrm{Cx} 43$ hemichannels has been shown in an osteocyte-like cell line in response to mechanical strain [35]. Paracrine processes implicating $\mathrm{Cx} 43$ hemichannels and $\mathrm{NAD}^{+}$have been demonstrated in smooth myocytes, 3T3 murine fibroblasts, hippocampal neurons, and human haemopoietic stem cells [36]. More recently, in mesenchymal stem cells, $\mathrm{Cx} 43$ hemichannels were described to be implicated in the secretion of angiogenic factors, e.g. vascular endothelial growth factor and basic fibroblast growth factor, under hypoxic stress [37]. Concerning cell death, hemichannel opening under ischemic stress results in ATP release and thus in necrosis [23]. This opening is induced in part by the dephosphorylation of $\mathrm{Cx} 43$ hemichannels. In the context of cardioprotection, it has been shown that pre-conditioning favours the phosphorylation of $\mathrm{Cx} 43$ by protein kinase $\mathrm{C}$, which prevents hemichannel opening [38]. Otherwise, Cx43 channels expressed in the mitochondria have been proposed to participate in cell survival by regulating the mitochondrial $\mathrm{K}_{\mathrm{ATP}}$ channel activity [39] and cytochrome $C$ release [40].

The channel-independent properties of $\mathrm{Cx}$ are receiving more and more attention in the context of cell growth, migration, development, signalling and cell death. Evidence of the channel-independent effects of $\mathrm{Cx}$ has been highlighted in many studies about tumourigenesis. In this context, it has been shown that usually $\mathrm{Cx} 43, \mathrm{Cx} 32$ and Cx31.1 inhibit cell proliferation, $\mathrm{Cx} 43$ and $\mathrm{Cx} 26$ inhibit cell growth, $\mathrm{Cx} 43, \mathrm{Cx} 32$ and $\mathrm{Cx} 31.1$ inhibit cell migration and $\mathrm{Cx} 43$ and $\mathrm{Cx} 32$ promote apoptosis [for a review, see 41]. Cx channel-independent effects have also been demonstrated in brain cells. For example, $\mathrm{Cx} 32$ is proposed to play a role in Schwann cell proliferation mediated by neuregulin-1 [42], and Cx43 is described to participate in the regulation of polarized cell movement which is essential for the directional migration of neural crest cells [43] and in astrocyte proliferation and wound closure after scratch wound injuries [44]. Channel-independent effects on cell proliferation have been linked to the implication of $\mathrm{Cx}$ proteins in the production and activity of several cell cycle regulators [45-47] or to their interactions with growth regulator proteins such as CCN3 [48]. Concerning cell migration, the channel-independent effects appear to be mainly due to the interaction of the $\mathrm{CT}$ part of the $\mathrm{Cx}$ with the cytoskeleton but also to effects on purinergic receptors and enzymes (e.g. ERK, PKC, Src and p38) [49-52]. In HL1 cardiomyocytes, it has been shown that $\mathrm{Cx} 43$ is implicated in the regulation of transforming growth factor (TGF)- $\beta$ function by interaction with $S \operatorname{mad} 2 / 3$ and microtubules [53]. Finally, the implication of Cx proteins in cell death has been proposed due to the nuclear localization of Cx in transfected cells [54], alteration of the expression of pro-apoptotic proteins including Bax, caspase- 6 and caspase- 9 in cells from $\mathrm{Cx} 43$ knockout mice [55] and the direct association of $\mathrm{Cx}$ with apoptotic proteins (e.g. Bax and Bak) [56].

\section{Cx Expression and Function in Healthy Vessels}

Four $\mathrm{Cx}$ are present in a healthy vascular wall: $\mathrm{Cx} 37$, $\mathrm{Cx} 40, \mathrm{Cx} 43$ and $\mathrm{Cx} 45$; their expression varies with the vascular territory and species. Usually, Cx37 and $\mathrm{Cx} 40$ are co-expressed in ECs, while $\mathrm{Cx} 43$ and $\mathrm{Cx} 45$ are mostly present in SMCs (fig. 2a). Of note, Cx43 has also been described in ECs of large vessels in rabbits, hamsters and rats. Homomeric and heteromeric connexons and homocellular and heterocellular GJ channels are found in the vascular wall between ECs, between SMCs and in some cases between ECs and SMCs, allowing the passage of transverse and longitudinal signals in the vessel wall [5759]. The importance of vascular $C x$ has been demonstrated by the fact that their deletion alters normal vascular functioning. For example, Cx45 knockout mice die in utero due to the interruption of vessel maturation [60], and $\mathrm{Cx} 43$ knockout mice die shortly after birth due to cardiac malformations resulting in obstruction of the outflow tract [61]. Although Cx40 knockout mice are viable, they are hypertensive [62] and display an increased sensitivity for cardiac arrhythmias $[63,64]$. The double deletion of $\mathrm{Cx} 37$ and $\mathrm{Cx} 40$ in mice induces embryonic death due to an excessive dilation of blood vessels [65]. Physiological control of the vascular tone is in part regulated by GJ inter-cellular communication. Indeed, GJ are implicated in the radial transmission of hyperpolarization from ECs to SMCs [the endothelium-derived hyperpolarizing factor (EDHF) phenomenon] and in the longitudinal transmission of electrical signals [66]. Cx37 and $\mathrm{Cx} 40$ are co-expressed at the level of the myoendothelial junctions [67]. The role of the different $\mathrm{Cx}$ in vascular tone has been investigated in vitro by targeting gap junctional communication and in vivo using transgenic animals. For example, $\alpha$-glycyrrhetinic acid, which inhibits gap junctional communication, blocks the EDHF phe- 


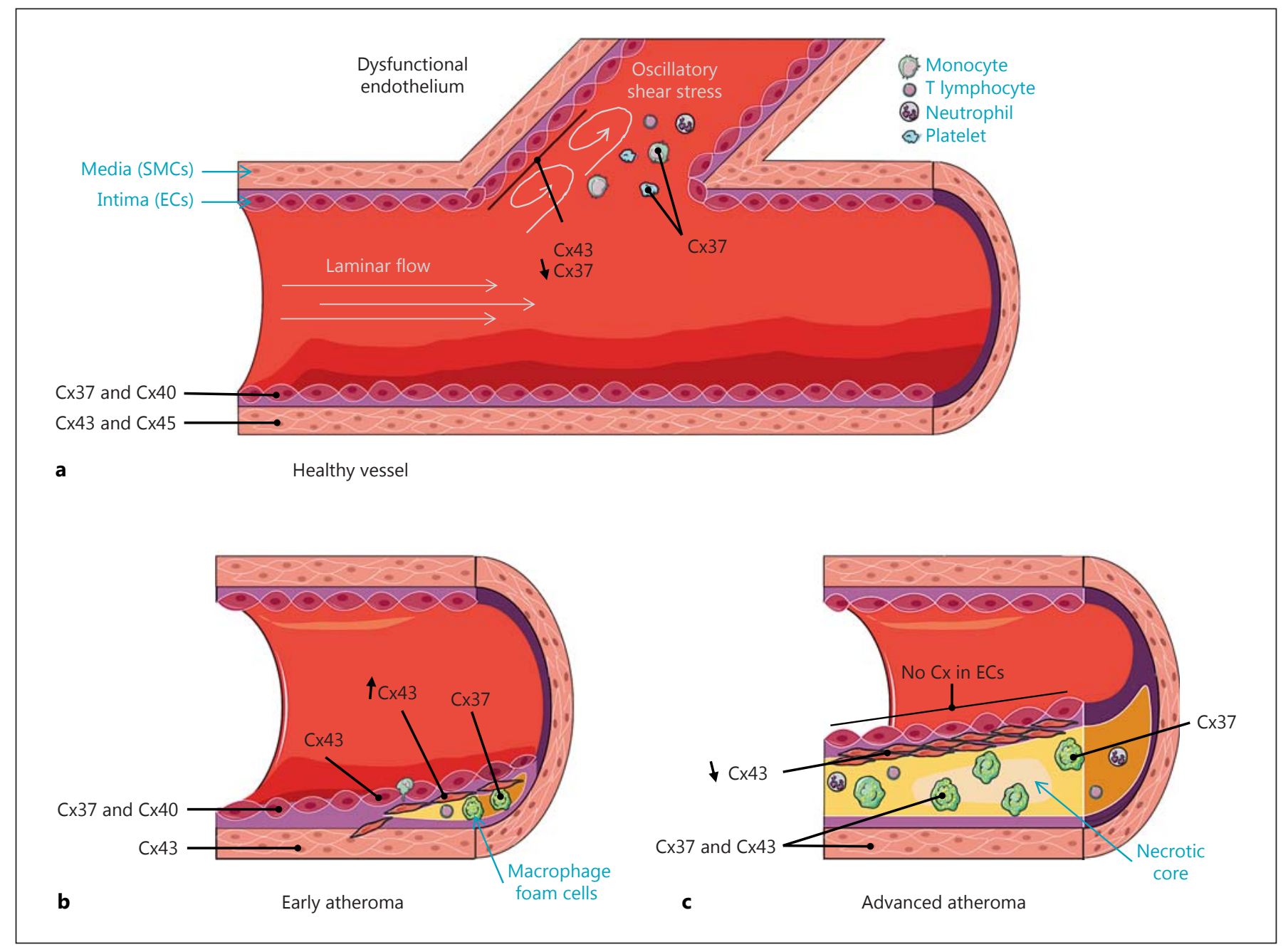

Fig. 2. Schematic representation of Cx expression in healthy vessels and during atherosclerosis. In healthy vessels, ECs express Cx37 and Cx40, whereas SMCs express Cx43 and Cx45 (a). Oscillatory shear stress present at the arterial bifurcation induces upand downregulation of $\mathrm{Cx} 43$ and $\mathrm{Cx} 37$ expression in ECs, respectively (a). Circulating monocytes and platelets express Cx37. Dur- ing atherosclerosis, the Cx43 expression in intimal SMCs is sequentially increased (b) and decreased (c), and the ECs that cover the atherosclerotic plaque do not express Cxs at all. In early atheroma, foam cells express only Cx37 (b), whereas in late atheromas, they may co-express $\mathrm{Cx} 37$ and $\mathrm{Cx} 43$ depending on their location in the plaque (c). nomenon [68]. The use of specific peptides targeting $\mathrm{Cx} 37, \mathrm{Cx} 40$ or $\mathrm{Cx} 43$ in the rat hepatic artery has shown that the inhibition of the EDHF response depends on more than one Cx subtype [69] and that Cx37 and Cx40 are implicated in endothelium-dependent subintimal smooth muscle hyperpolarization whereas $\mathrm{Cx} 43$ is involved in the spread of subintimal hyperpolarization through the media [70]. In rat mesenteric arteries, EDHFmediated dilation seems to depend exclusively on $\mathrm{Cx} 40$ [71]. Using arterioles of $\mathrm{Cx} 40$-deficient mice, it has been demonstrated that $\mathrm{Cx} 40$ plays an important role in the propagation of acetylcholine- or bradykinin-induced vasodilation [72] and in vasodilation induced by electrical stimulation [73]. The role of $\mathrm{Cx} 40$ in vasodilation has been confirmed in Cx40K145 mice in which the expression of $\mathrm{Cx} 45$ instead of $\mathrm{Cx} 40$ cannot replace the function of $\mathrm{Cx} 40$ in the conduction of endothelium-dependent dilations along arterioles [74]. In contrast to $\mathrm{Cx} 40, \mathrm{Cx} 37$ deficiency does not modify vasodilation induced by acetylcholine [75]. Moreover, along the arterial wall, Cx expression is influenced by blood flow. Indeed, oscillatory shear stress present at the branch points of arteries in- 
duces $\mathrm{Cx} 43$ expression in ECs [76], whereas the Cx37 expression is reduced [77] (fig. 2a). The disturbed shear stress in these regions induces endothelial dysfunction and makes them a starting point for atherosclerosis plaque development [78].

\section{Cx in Atherosclerosis-Induced Vascular Remodelling}

Atherosclerosis is a progressive pathology that takes place in the intima of large- and medium-sized arteries. Experimental studies on atherosclerosis are generally performed using mice deficient in apolipoprotein $\mathrm{E}\left(\mathrm{ApoE}^{-/-}\right)$or low-density lipoprotein-receptor $\left(\mathrm{LDLR}^{-/-}\right)$[2]. The additional deletion of $\mathrm{Cx} 37, \mathrm{Cx} 40$ or $\mathrm{Cx} 43$ in these atherosclerosis-susceptible mice permits consideration of the implication of each $\mathrm{Cx}$ in atherogenesis $[29,79,80]$. The pattern of Cx expression during atherosclerotic plaque development is schematically presented in figure 2.

The initiating step of atherosclerosis is endothelial dysfunction [81] induced by a disturbed blood flow at the arterial bifurcations and by typical cardiovascular risk factors such as dyslipidaemia, hyperglycaemia, hypertension or free radicals. As mentioned above, Cx expression is changed at the arterial branch points; $\mathrm{Cx} 43$ appears in ECs whereas Cx37 expression is downregulated [76, 77, 82] (fig. 2a). The Cx37 expression in ECs is regulated by the flow-responsive transcription factor KLF2 [77]. Endothelial dysfunction is associated with altered expression and function of the endothelial nitric oxide synthase (eNOS) that limits the vasoprotective properties of nitric oxide (NO) [83]. It has been highlighted that $\mathrm{Cx} 37$ is a direct protein partner of eNOS and that mutual functional regulation exists between $\mathrm{Cx} 37$ and eNOS in ECs [84]. In fact, the downregulation of Cx37 in bEnd. 3 cells leads to an increase in NO release, and the transfection of N2A cells with eNOS-mimetic peptides modifies Cx37 GJ channel properties. Moreover, eNOS expression has also been shown to be altered in mice deficient in $\mathrm{Cx} 40$ [85].

Parallel to this effect on eNOS, the activation of ECs leads to an increase in the expression of different cell adhesion molecules and to the secretion of chemoattractants which induces the recruitment of monocytes, $\mathrm{T}$ lymphocytes, neutrophils and platelets [4, 86, 87]. Circulating monocytes express $\mathrm{Cx} 37$ in basal conditions [29] (fig. 2a) and $\mathrm{Cx} 43$ upon activation by tumour necrosis factor (TNF)- $\alpha$ and interferon (IFN) $-\gamma$ [88]. At the level of the dysfunctional endothelium, monocytes transmi- grate between ECs to infiltrate into the arterial intima where they mature into macrophages. These intimal macrophages accumulate lipids and transform into foam cells, creating the earliest atherosclerotic lesion. The development of atherosclerotic lesions in the thoracic-abdominal aorta and in the aortic sinus is accelerated in $\mathrm{Cx} 37^{-/-} \mathrm{ApoE}^{-/-}$mice compared to controls $\left(\mathrm{C} \times 37^{+/+} \mathrm{ApoE}^{-/-}\right)$, suggesting a protective effect of $\mathrm{Cx} 37$ against atherosclerosis [29]. Adoptive transfer of Cx37expressing and $\mathrm{Cx} 37$-deficient fluorescent monocytes or macrophages in control and $\mathrm{C} \times 37^{-/-} \mathrm{ApoE}^{-/-}$mice revealed that the deletion of $\mathrm{Cx} 37$ in monocytes/macrophages increased the number of these leucocytes in atherosclerotic plaques [29]. Interestingly, the presence or absence of Cx37 in ECs did not influence the transmigration of monocytes/macrophages. In addition, in vitro assays showed that the absence or inhibition of $\mathrm{Cx} 37$ hemichannels in the H36.12j mouse peritoneal macrophage cell line reduced the release of ATP by macrophages and increased their adhesion [29]. As it is known that ATP is implicated in inflammation and can pass through GJ channels and hemichannels [89], it has been proposed that $\mathrm{Cx} 37$ protects against atherosclerosis by regulating ATP-dependent monocyte adhesion [29]. A similar role was recently proposed for $\mathrm{Cx} 43$ [90]. Altogether, these results point to the importance of $\mathrm{Cx}$ hemichannels in monocytes during atherosclerotic plaque development and show that Cx37 GJ channels between ECs or between ECs and leucocytes play a relatively minor role in the disease process. Cx expression in T lymphocytes is not consistently reported, but it seems that $\mathrm{Cx} 43$ expression in these cells may play a role in their activation [91]. The role of $\mathrm{Cx} 43$ in T cells has not yet been described in the context of atherosclerosis. Concerning neutrophils, $\mathrm{Cx} 43$ expression has been found by some groups after specific stimulation such as with TNF- $\alpha$, IFN- $\gamma$ or lipopolysaccharide [92-94], whereas others have reported the absence of Cx43 [95]. It was recently proposed that $\mathrm{Cx} 43$ hemichannels present in neutrophils influence their adhesion by modulating ATP release [96].

During atherosclerotic plaque development, the ECs present in the shoulder part of the atherosclerotic lesion express $\mathrm{Cx} 43$ [97] while the ECs covering the atherosclerotic plaque do not express $\mathrm{Cx}$ at all [97] (fig. 2b, c). The mechanism implicated in the downregulation of $\mathrm{Cx}$ expression in these ECs is not yet known, but it has been described that inflammatory mediators such as TNF- $\alpha$ are able to regulate $\mathrm{Cx}$ expression in human umbilical vein ECs [98]. Young mice in which Cx40 was deleted only in ECs (Cx40del mice) developed atherosclerotic 
plaques in the aortic sinus spontaneously (i.e. without a high-cholesterol diet) [79]. The progression of these atherosclerotic lesions was increased after 5 or 10 weeks of a high-cholesterol diet, illustrating a protective role of endothelial $\mathrm{Cx} 40$ in atherogenesis. The transmigration of monocytes from the blood to the intima depends critically on adhesion molecules such as vascular cell adhesion molecule (VCAM)-1. VCAM-1 expression is regulated by the activity of the $5^{\prime}$-ecto-nucleotidase CD73 at the surface of ECs [99]. Interestingly, Cx40del mice showed a decreased expression of CD73 in en face staining of the aorta and increased VCAM-1 expression [79]. In vitro, it has been confirmed that blocking endothelial $\mathrm{Cx} 40$ with anti-sense increases monocyte adhesion on a monolayer of bEnd. 3 cells which normally constitutively express CD73 and Cx40. Thus, reducing the $\mathrm{Cx} 40$ expression limits the spread of CD73-evoked anti-inflammatory signalling between ECs, leading to increased monocyte adhesion [79].

Activated cells present in the atherosclerotic lesion secrete cytokines, chemokines and growth factors that induce the migration of SMCs from the media to the intima of the atherosclerotic lesions. The $\mathrm{Cx} 43$ expression in the SMCs present in the intima temporarily increases and declines later in the process $[97,100]$ (fig. 2c). The mechanism that regulates $\mathrm{Cx} 43$ expression in SMCs during atherosclerosis is not known, but a recent study performed in the human radial artery suggests that the transcription factor NFkB is involved in the regulation of $\mathrm{Cx} 43$ expression in SMCs [101]. In the intima, SMCs proliferate and secrete extracellular matrix components which participate in the formation of a strong fibrous cap around the atherosclerotic plaque. This process seems to be associated with the increased expression of Cx43 in SMCs [102, 103 ] and with modifications in the phosphorylation status of $\mathrm{Cx} 43$ [104]. As described by the authors, the phosphorylation of $\mathrm{Cx} 43$ on serine $279 / 282$, but not on serine 368 , increased the vascular SMC proliferation. Moreover, treatment of human aortic SMCs with TGF- $\beta$ upregulates $\mathrm{Cx} 43$ expression which is correlated with an increased synthetic activity [105]. Overall, these data suggest that atherosclerotic plaque development is influenced not only by the level of Cx43 expression but also by posttranslational modifications. Cx37 expression has been observed in medial SMCs of advanced atherosclerotic lesions [97] (fig. 2c). A micro-array analysis showed that, out of $>15,000$ genes, 106 genes were significantly differentially expressed in $\mathrm{Cx} 37^{-/-} \mathrm{ApoE}^{-/-}$young mice before diet in comparison with $\mathrm{Cx} 37^{+/+} \mathrm{ApoE}^{-/-}$; differences mostly involved genes implicated in cell-to-cell signalling

Cx in Atherosclerosis and Restenosis and interactions (e.g. mitogen-activated kinases 1 and 3), cellular compromise (e.g. heat shock proteins HSPA1B and HSPB1) and nutritional disease pathways (e.g. adiponectin and resistin) [106]. This study also showed important changes in the genes and proteins implicated in vascular calcification and matrix degradation in aortas of $\mathrm{Cx} 37^{-/-} \mathrm{ApoE}^{-/-}$mice after 18 weeks of a cholesterol-rich diet. Thus, Cx37 deficiency seems to alter the global differential gene expression profiles of young mice towards a pro-inflammatory phenotype, which could affect advanced plaque stability.

In the centre of the atherosclerotic plaque, foam cells die and release lipids that form the necrotic core of this lesion. Macrophage foam cells present in the necrotic core co-express $\mathrm{Cx} 43$ and $\mathrm{Cx} 37$ while foam cells present in the periphery of the necrotic core only express $\mathrm{Cx} 37$ (fig. 2c) $[97,107]$. Cx43 ${ }^{+/-} \mathrm{LDLR}^{-/-}$mice on a high-cholesterol diet showed about a 50\% reduction in atherosclerotic plaque development in the thoracic-abdominal aorta and in the aortic sinus in comparison to $\mathrm{Cx} 43^{+/+} \mathrm{LDLR}^{-/-}$mice [80]. Moreover, the atherosclerotic plaques of these $\mathrm{Cx} 43^{+/-} \mathrm{LDLR}^{-/-}$mice presented smaller lipid cores, fewer macrophages and more SMCs and interstitial collagen than those of $\mathrm{Cx} 43^{+/+} \mathrm{LDLR}^{-/-}$mice. In humans, such a plaque phenotype is considered more stable and thus less vulnerable to plaque rupture. The exact role of the different atheroma-associated cell types that express Cx43 (SMCs, ECs and macrophages) is still under investigation. Preliminary data have shown that the endothelial-specific deletion of $\mathrm{Cx} 43$ in mice has beneficial effects on both the natural progression and the composition of atherosclerotic lesions [108].

Atherosclerotic plaque may give rise to the formation of a luminal thrombotic occlusion due to the superficial erosion of the endothelial monolayer or to rupture of the plaques' fibrous cap $[109,110]$. As a consequence of plaque erosion or rupture, platelets come into contact with extra-cellular matrix, leading to their activation and subsequent thrombus formation. Upon activation, the morphology of the platelets changes and they express molecules to enhance their adhesion to ECs and inflammatory cells. Angelillo-Scherrer et al. [111] recently demonstrated that platelets express $\mathrm{Cx} 37$ and that GJ communication between $\mathrm{Cx} 37$-expressing platelets provides a mechanism for limiting thrombus propensity. More recent studies seem to implicate the $\mathrm{Cx} 37$ and $\mathrm{Cx} 40$ hemichannels in thrombus formation as well, even though the authors leave unexplained how hemichannels may open in the presence of a fair amount of extra-cellular calcium needed to induce platelet aggregation [112, 113]. 
Thrombus formation may lead to myocardial infarction and stroke, which are responsible for a large percentage of sudden deaths worldwide [3]. These clinical complications of atherosclerosis are commonly treated by angioplasty followed by stent implantation [114]. Although angioplasty and stent implantation have tremendously contributed to the increase in survival rates, these procedures induce de-endothelialization which increases the risk of thrombosis shortly or even later after the intervention, and they injure the vessel wall, favouring a vascular reaction which leads to restenosis.

\section{Cx in Restenosis-Induced Vascular Remodelling}

Restenosis is a process that occurs generally within 6 months after angioplasty or stent implantation. Restenosis is due to an exaggerated cellular response at the site of the intervention, leading to formation of the neointima and to re-occlusion of the artery [8]. The elaboration of drug-eluting stents has helped tremendously to prevent restenosis by inhibiting neointimal hyperplasia, but drugeluting stents also delay re-endothelialization, leading to late in-stent thrombosis [115]. The molecular pathways implicated in all of these phenomena remain poorly understood. The development of the model of balloon injury in animals, and certainly in hypercholesterolemic mice [116], allows detailed investigation of the proteins involved in the restenotic process such as $\mathrm{Cx}$ [117]. The pattern of $\mathrm{Cx}$ expression in restenosis is schematically presented in figure 3.

When an occluded artery is re-opened by angioplasty, the surgical procedure causes damage to the vascular wall, inducing the recruitment and infiltration of leucocytes into the damaged site, a surge in cytokines and growth factors and a phenotypic switch of medial SMCs that become activated, begin to proliferate and migrate towards the intima. Several proteins, including $\mathrm{Cx}$, have been described to regulate SMC phenotypic modulation, proliferation and migration. The possible involvement of $\mathrm{Cx}$ in restenosis after a balloon catheter injury was first described by Yeh et al. [118] in 1997 . In the rat carotid artery, they carefully followed the Cx43 expression for 14 days after ballooning and showed an upregulation of this expression in medial and intimal SMCs, with a higher expression in the neointima. In addition, the size of the GJ was larger between SMCs in the intima than between SMCs of the media. In this model of the rat carotid artery, restenosis was mainly due to the migration and proliferation of SMCs and, to a lesser extent, to leucocyte infiltra- tion [118]. In hypercholesterolaemic mice, a reduced expression of $\mathrm{Cx} 43\left(\mathrm{Cx} 43^{+/-} \mathrm{LDLR}^{-/-}\right.$mice $)$is associated with the limitation of neointima formation in comparison to mice with a normal expression of $\mathrm{Cx} 43$ $\left(\mathrm{Cx} 43^{+/+} \mathrm{LDLR}^{-/-}\right)$[117]. In addition, the in vivo macrophage infiltration is lower in the carotid intima of $\mathrm{Cx} 43^{+/-} \mathrm{LDLR}^{-/-}$mice than in $\mathrm{Cx} 43^{+/+} \mathrm{LDLR}^{-/-}$mice, and in vitro experiments have shown that macrophages from $\mathrm{C} \times 43^{+/-} \mathrm{LDLR}^{-/}$mice have a reduced migration capacity compared to macrophages from $\mathrm{Cx} 43^{+/+} \mathrm{LDLR}^{-/-}$ mice. Interestingly, conditioned medium obtained from $\mathrm{C} \times 43^{+/+} \mathrm{LDLR}^{-/-}$macrophages induced, in vitro, a higher migration of SMCs than conditioned medium obtained from $\mathrm{Cx} 43^{+/-} \mathrm{LDLR}^{-/-}$macrophages, suggesting that these macrophages secrete fewer chemoattractant factors than control macrophages. Two types of SMCs have been described in rat aortas [119] and in porcine coronary arteries [120]. The differentiated SMCs, called spindle-shaped SMCs (S-SMCs), present the classical 'hills-and-valleys' growth pattern and the rhomboid SMCs (R-SMCs) have high proliferative, migratory and proteolytic activities [120]. Interestingly, R-SMCs are more present in the intimal thickening induced by stent implantation in porcine coronary arteries than S-SMCs [120], and Cx43 expression is strongly upregulated in this intimal thickening whereas $\mathrm{Cx} 40$ is absent [103]. In vitro experiments have confirmed that $\mathrm{Cx} 43$ and $\mathrm{Cx} 40$ are co-expressed in SSMCs whereas R-SMCs expressed only Cx43 [103]. In addition, R-SMC migration induced by platelet-derived growth factor (PDGF)-BB is highly reduced in the presence of $\mathrm{Cx} 43$ anti-sense or $\mathrm{Cx} 43$ blocking peptide [103], suggesting that $\mathrm{Cx} 43$ expression and channel function regulate the migration process of R-SMCs. Furthermore, Cx43 anti-sense prevents PDGF-BB-induced deleterious phenotypic changes of porcine S-SMCs to R-SMCs [103]. In the rat model of a balloon injury, the downregulation of Cx43 expression also inhibits SMC proliferation [121]. To specifically study the role of Cx43 in SMCs, Liao et al. [122] generated mice in which the deletion of the $\mathrm{Cx} 43$ gene was confined to SMCs, and they performed carotid artery denudation using a guide wire. Seven days after the surgery, the neointima in these mice was larger than the neointima in control mice. The opposite results obtained between the studies have not yet been explained but are likely due to differences in mouse models (deletion of Cx43 in SMCs vs. half of Cx43 in all cells) and methodologies (balloon injury with hypercholesterolaemia vs. wire injury) used. Finally, in New Zealand white rabbits, balloon injuries induced an increase in Cx40 mRNA and protein expression in neointimal SMCs $[123,124]$. Inter- 


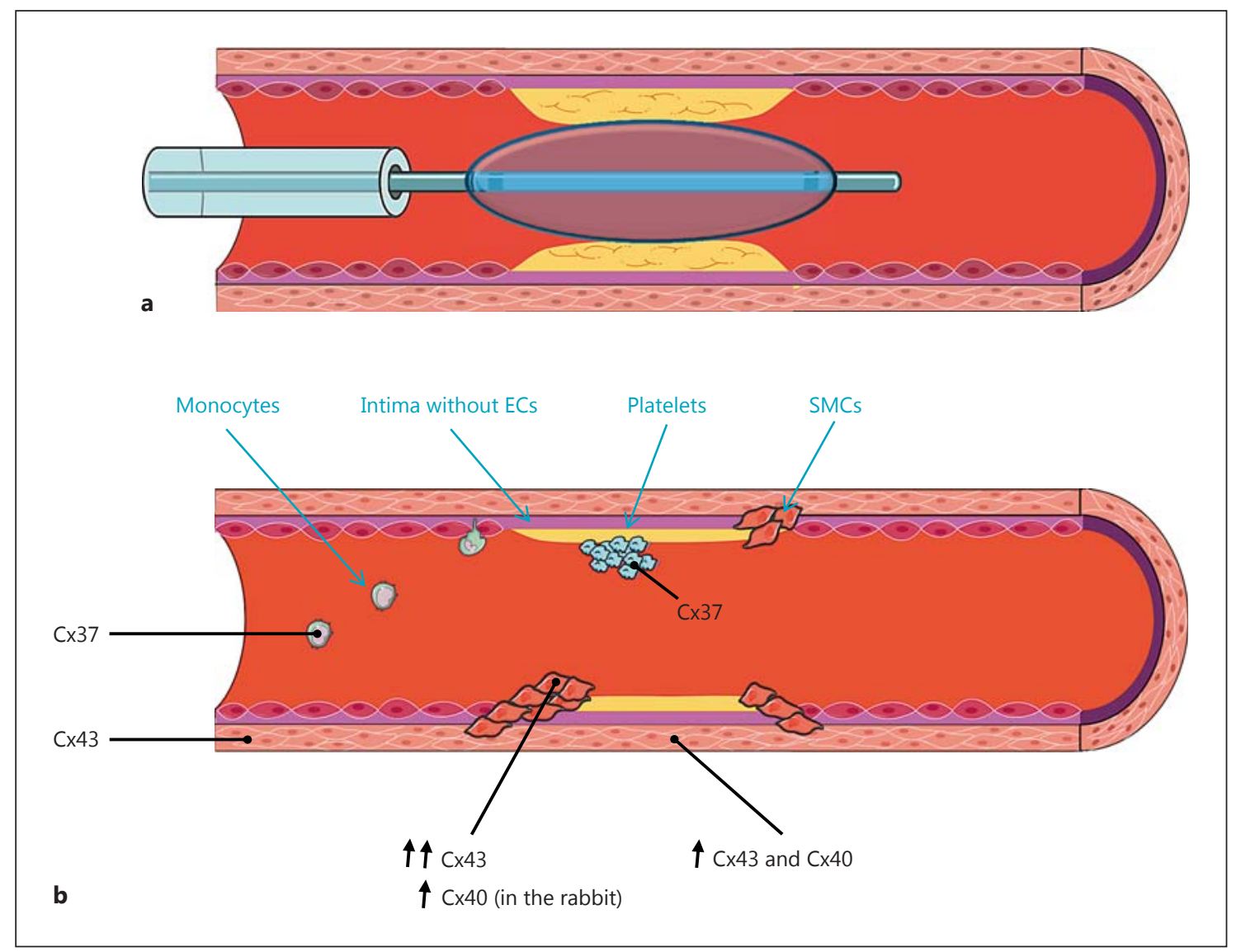

Fig. 3. Schematic representation of Cx expression during restenosis. Angioplasty allows re-opening of an occluded artery (a). However, this surgical procedure may also induce the recruitment and infiltration of leucocytes into the damaged site, the proliferation and migration of SMCs from the media towards the intima and platelet aggregation at the site of the intervention (b). During this process, the main modification observed in Cx expression is an upregulation of $\mathrm{Cx} 43$ and $\mathrm{Cx} 40$ in SMCs.

estingly, in the presence of statins, a molecule with antiinflammatory and anti-proliferative properties, the formation of the neointima induced by the balloon injury is reduced and the expression of $\mathrm{Cx} 43$ and $\mathrm{Cx} 40$ in the rabbit iliac artery is less important [123]. Treatment of New Zealand white rabbits with ramipril, an angiotensin-converting enzyme inhibitor, also seems to inhibit neointimal formation after a balloon injury and it appears to downregulate the expression of $\mathrm{Cx} 43 \mathrm{mRNA}$ and protein [124].

The progression of restenosis after vascular surgery may also be influenced by thrombosis at the site of the injury. Indeed, increased platelet activation at the site of the injury results in increased PDGF-BB secretion, which then has additional effects on SMCs. The role of platelet Cx37 in this respect has not yet been investigated.

$\mathrm{Cx}$ in Atherosclerosis and Restenosis
Although it has been shown that the expression of $\mathrm{Cx}$ is modified after vascular injury, their roles in restenosis are not yet fully clear at the molecular level. Studies of Cx as modulators of migration or proliferation suggest that they may play a role in these processes via either channeldependent (hemichannel or GJ channel) or channel-independent interactions with cytoskeletal proteins, junctional proteins or enzymes $[51,125]$.

\section{Conclusion}

This review provides an overview of the role of $\mathrm{Cx}$ in vascular remodelling associated with atherosclerosis and restenosis. The importance of each $\mathrm{Cx}$ is revealed by the use of transgenic mice, transfected cells, specific blocking 
peptides and anti-sense. Further studies are needed to more fully understand the exact role of each Cx expressed in the different cell types (ECs, SMCs and inflammatory cells) implicated in these processes. The development of treatments targeting $\mathrm{Cx}$ might hold promise, particularly for limiting the deleterious consequences of angioplasty and stent implantation.

\section{Acknowledgements}

This work was supported by the Swiss National Science Foundation (No. 310030_143343/1), the Fondation Schmidheiny and the Fondation SwissLife. This review is based on a lecture presented by the author at a symposium on vascular remodelling organized by the German Centre for Cardiovascular Research (DZHK), partner site Munich Heart Alliance, Munich, Germany, in February 2013.

\section{References}

$\checkmark 1$ Kolodgie FD, Narula J, Yuan C, Burke AP, 13 Laird DW: Life cycle of connexins in health Finn AV, Virmani R: Elimination of neoangiogenesis for plaque stabilization: is there a role for local drug therapy? J Am Coll Cardiol 2007;49:2093-2101.

-2 Yla-Herttuala S, Bentzon JF, Daemen M, Falk E, Garcia-Garcia HM, Herrmann J, Hoefer I, Jukema JW, Krams R, Kwak BR, Marx N, Naruszewicz M, Newby A, Pasterkamp G, Serruys PW, Waltenberger J, Weber C, Tokgozoglu L: Stabilisation of atherosclerotic plaques: position paper of the European Society of Cardiology (ESC) Working Group on atherosclerosis and vascular biology. Thromb Haemost 2011;106:1-19.

3 Libby P, Ridker PM, Hansson GK: Progress and challenges in translating the biology of atherosclerosis. Nature 2011;473:317-325.

4 Weber C, Noels H: Atherosclerosis: current pathogenesis and therapeutic options. Nat Med 2011;17:1410-1422.

-5 Johnson JL, Newby AC: Macrophage heterogeneity in atherosclerotic plaques. Curr Opin Lipidol 2009;20:370-378.

-6 Ley K, Miller YI, Hedrick CC: Monocyte and macrophage dynamics during atherogenesis. Arterioscler Thromb Vasc Biol 2011;31: 1506-1516.

-7 Ponnuswamy P, Van Vre EA, Mallat Z, Tedgui A: Humoral and cellular immune responses in atherosclerosis: spotlight on B- and T-cells. Vascul Pharmacol 2012;56:193-203.

-8 Serruys PW, Luijten HE, Beatt KJ, Geuskens R, de Feyter PJ, van den Brand M, Reiber JH, ten Katen HJ, van Es GA, Hugenholtz PG: Incidence of restenosis after successful coronary angioplasty: a time-related phenomenon - a quantitative angiographic study in 342 consecutive patients at 1,2,3, and 4 months. Circulation 1988;77:361-371.

9 Sohl G, Willecke K: Gap junctions and the connexin protein family. Cardiovasc Res 2004;62:228-232

10 Kumar NM, Gilula NB: The gap junction communication channel. Cell 1996;84:381388.

11 Sohl G, Willecke K: An update on connexin genes and their nomenclature in mouse and man. Cell Commun Adhes 2003;10:173-180.

-12 Martin PE, Evans WH: Incorporation of connexins into plasma membranes and gap junctions. Cardiovasc Res 2004;62:378-387. and disease. Biochem J 2006;394:527-543.

14 Solan JL, Lampe PD: Connexin43 phosphorylation: structural changes and biological effects. Biochem J 2009;419:261-272.

15 Saez JC, Berthoud VM, Branes MC, Martinez $\mathrm{AD}$, Beyer EC: Plasma membrane channels formed by connexins: their regulation and functions. Physiol Rev 2003;83:1359-1400.

16 Herve JC, Derangeon M, Sarrouilhe D, Giepmans BN, Bourmeyster N: Gap junctional channels are parts of multiprotein complexes. Biochim Biophys Acta 2012;1818:1844-1865.

17 Palatinus JA, Rhett JM, Gourdie RG: The connexin43 carboxyl terminus and cardiac gap junction organization. Biochim Biophys Acta 2012;1818:1831-1843.

18 Marquez-Rosado L, Solan JL, Dunn CA, Norris RP, Lampe PD: Connexin 43 phosphorylation in brain, cardiac, endothelial and epithelial tissues. Biochim Biophys Acta 2012;1818: 1985-1992.

19 Duffy HS, Delmar M, Spray DC: Formation of the gap junction nexus: binding partners for connexins. J Physiol Paris 2002;96:243-249.

20 Evans WH, Martin PE: Gap junctions: structure and function (review). Mol Membr Biol 2002;19:121-136

21 Goodenough DA, Paul DL: Beyond the gap: functions of unpaired connexon channels. Nat Rev Mol Cell Biol 2003;4:285-294.

22 Herve JC, Derangeon M: Gap-junction-mediated cell-to-cell communication. Cell Tissue Res 2013;352:21-31.

23 Decrock E, Vinken M, De Vuyst E, Krysko DV, D'Herde K, Vanhaecke T, Vandenabeele P, Rogiers V, Leybaert L: Connexin-related signaling in cell death: to live or let die? Cell Death Differ 2009; 16:524-536.

24 John S, Cesario D, Weiss JN: Gap junctional hemichannels in the heart. Acta Physiol Scand 2003;179:23-31.

- 25 Derouette JP, Desplantez T, Wong CW, Roth I, Kwak BR, Weingart R: Functional differences between human $\mathrm{Cx} 37$ polymorphic hemichannels. J Mol Cell Cardiol 2009;46: 499-507.

26 Saez JC, Retamal MA, Basilio D, Bukauskas FF, Bennett MV: Connexin-based gap junction hemichannels: gating mechanisms. Biochim Biophys Acta 2005; 1711:215-224.
27 Goodenough DA, Paul DL: Beyond the gap: functions of unpaired connexon channels. Nat Rev Mol Cell Biol 2003;4:285-294.

28 Saez JC, Schalper KA, Retamal MA, Orellana JA, Shoji KF, Bennett MV: Cell membrane permeabilization via connexin hemichannels in living and dying cells. Exp Cell Res 2010; 316:2377-2389.

29 Wong CW, Christen T, Roth I, Chadjichristos CE, Derouette JP, Foglia BF, Chanson M, Goodenough DA, Kwak BR: Connexin37 protects against atherosclerosis by regulating monocyte adhesion. Nat Med 2006;12:950954.

30 Anselmi F, Hernandez VH, Crispino G, Seydel A, Ortolano S, Roper SD, Kessaris N, Richardson W, Rickheit G, Filippov MA, Monyer H, Mammano F: ATP release through connexin hemichannels and gap junction transfer of second messengers propagate $\mathrm{Ca}^{2+}$ signals across the inner ear. Proc Natl Acad Sci USA 2008;105:18770-18775.

- 31 Robertson J, Lang S, Lambert PA, Martin PE: Peptidoglycan derived from Staphylococcus epidermidis induces connexin 43 hemichannel activity with consequences on the innate immune response in endothelial cells. Biochem J 2010;432:133-143.

32 Ye ZC, Wyeth MS, Baltan-Tekkok S, Ransom BR: Functional hemichannels in astrocytes: a novel mechanism of glutamate release. J Neurosci 2003;23:3588-3596.

-33 Kamermans M, Fahrenfort I, Schultz K, Janssen-Bienhold U, Sjoerdsma T, Weiler R: Hemichannel-mediated inhibition in the outer retina. Science 2001;292:1178-1180.

34 Ankarcrona M, Dypbukt JM, Bonfoco E, Zhivotovsky B, Orrenius S, Lipton SA, Nicotera P: Glutamate-induced neuronal death: a succession of necrosis or apoptosis depending on mitochondrial function. Neuron 1995; 15: 961-973.

35 Cherian PP, Siller-Jackson AJ, Gu S, Wang X, Bonewald LF, Sprague E, Jiang JX: Mechani$\mathrm{cal}$ strain opens connexin 43 hemichannels in osteocytes: a novel mechanism for the release of prostaglandin. Mol Biol Cell 2005; 16:31003106.

36 De Flora A, Zocchi E, Guida L, Franco L, Bruzzone S: Autocrine and paracrine calcium signaling by the CD38/NAD+/cyclic ADP-ribose system. Ann NY Acad Sci 2004;1028:176-191. 
- 37 Wang DG, Zhang FX, Chen ML, Zhu HJ, Yang B, Cao KJ: Cx43 in mesenchymal stem cells promotes angiogenesis of the infarcted heart independent of gap junctions. Mol Med Rep 2014;9:1095-1102.

- 38 Schwanke U, Konietzka I, Duschin A, Li X, Schulz R, and Heusch G. No ischemic preconditioning in heterozygous connexin43-deficient mice. Am J Physiol Heart Circ Physiol 2002; 283: H1740-H1742.

- 39 Ruiz-Meana M, Rodriguez-Sinovas A, Cabestrero A, Boengler K, Heusch G, GarciaDorado D: Mitochondrial connexin43 as a new player in the pathophysiology of myocardial ischaemia-reperfusion injury. Cardiovasc Res 2008;77:325-333.

-40 Goubaeva F, Mikami M, Giardina S, Ding B, Abe J, Yang J: Cardiac mitochondrial connexin 43 regulates apoptosis. Biochem Biophys Res Commun 2007;352:97-103.

41 Zhou JZ, Jiang JX: Gap junction and hemichannel-independent actions of connexins on cell and tissue functions - an update. FEBS Lett 2014, Epub ahead of print.

-42 Freidin M, Asche S, Bargiello TA, Bennett MV, Abrams CK: Connexin 32 increases the proliferative response of Schwann cells to neuregulin-1 (Nrg1). Proc Natl Acad Sci USA 2009;106:3567-3572.

43 Xu X, Francis R, Wei CJ, Linask KL, Lo CW: Connexin 43-mediated modulation of polarized cell movement and the directional migration of cardiac neural crest cells. Development 2006;133:3629-3639.

44 Homkajorn B, Sims NR, Muyderman H: Connexin 43 regulates astrocytic migration and proliferation in response to injury. Neurosci Lett 2010;486:197-201.

-45 Qin H, Shao Q, Thomas T, Kalra J, AlaouiJamali MA, Laird DW: Connexin26 regulates the expression of angiogenesis-related genes in human breast tumor cells by both GJICdependent and -independent mechanisms. Cell Commun Adhes 2003;10:387-393.

46 Zhang W, Nwagwu C, Le DM, Yong VW, Song $\mathrm{H}$, Couldwell WT: Increased invasive capacity of connexin43-overexpressing malignant glioma cells. J Neurosurg 2003;99: 1039-1046.

-47 Johnstone SR, Best AK, Wright CS, Isakson BE, Errington RJ, Martin PE: Enhanced connexin 43 expression delays intra-mitotic duration and cell cycle traverse independently of gap junction channel function. J Cell Biochem 2010;110:772-782.

-48 Gellhaus A, Wotzlaw C, Otto T, Fandrey J, Winterhager E: More insights into the CCN3/ connexin 43 interaction complex and its role for signaling. J Cell Biochem 2010;110:129140.

-49 Behrens J, Kameritsch P, Wallner S, Pohl U, Pogoda K: The carboxyl tail of Cx43 augments p38 mediated cell migration in a gap junctionindependent manner. Eur J Cell Biol 2010;89: 828-838.
0 Laird DW: The gap junction proteome and its relationship to disease. Trends Cell Biol 2010; 20:92-101.

51 Kameritsch P, Pogoda K, Pohl U: Channelindependent influence of connexin 43 on cell migration. Biochim Biophys Acta 2012;1818: 1993-2001.

52 Crespin S, Bechberger J, Mesnil M, Naus CC, Sin WC: The carboxy-terminal tail of connexin43 gap junction protein is sufficient to mediate cytoskeleton changes in human glioma cells. J Cell Biochem 2010;110:589-597.

53 Dai P, Nakagami T, Tanaka H, Hitomi T, Takamatsu T: Cx43 mediates TGF-beta signaling through competitive Smads binding to microtubules. Mol Biol Cell 2007;18:2264-2273.

54 Huang RP, Fan Y, Hossain MZ, Peng A, Zeng ZL, Boynton AL: Reversion of the neoplastic phenotype of human glioblastoma cells by connexin 43 (cx43). Cancer Res 1998;58: 5089-5096.

55 Walker DL, Vacha SJ, Kirby ML, Lo CW: Connexin 43 deficiency causes dysregulation of coronary vasculogenesis. Dev Biol 2005; 284:479-498.

56 Kanczuga-Koda L, Sulkowski S, Koda M, Skrzydlewska E, Sulkowska M: Connexin 26 correlates with $\mathrm{Bcl}-\mathrm{xL}$ and $\mathrm{Bax}$ proteins expression in colorectal cancer. World J Gastroenterol 2005; 11:1544-1548.

57 de Wit C, Hoepfl B, Wolfle SE: Endothelial mediators and communication through vascular gap junctions. Biol Chem 2006;387:3-9.

- 58 Sandow SL, Looft-Wilson R, Doran B, Grayson TH, Segal SS, Hill CE: Expression of homocellular and heterocellular gap junctions in hamster arterioles and feed arteries. Cardiovasc Res 2003;60:643-653.

59 Looft-Wilson RC, Payne GW, Segal SS: Connexin expression and conducted vasodilation along arteriolar endothelium in mouse skeletal muscle. J Appl Physiol (1985) 2004;97: 1152-1158.

60 Kruger O, Plum A, Kim JS, Winterhager E, Maxeiner S, Hallas G, Kirchhoff S, Traub O, Lamers WH, Willecke K: Defective vascular development in connexin 45-deficient mice. Development 2000;127:4179-4193.

61 Reaume AG, de Sousa PA, Kulkarni S, Langille BL, Zhu D, Davies TC, Juneja SC, Kidder GM, Rossant J: Cardiac malformation in neonatal mice lacking connexin43. Science 1995;267:1831-1834.

62 de Wit C, Roos F, Bolz SS, Pohl U: Lack of vascular connexin 40 is associated with hypertension and irregular arteriolar vasomotion. Physiol Genomics 2003;13:169-177.

63 Simon AM, Goodenough DA, Paul DL: Mice lacking connexin 40 have cardiac conduction abnormalities characteristic of atrioventricular block and bundle branch block. Curr Biol 1998;8:295-298.

64 Kirchhoff S, Nelles E, Hagendorff A, Kruger O, Traub O, Willecke K: Reduced cardiac conduction velocity and predisposition to arrhythmias in connexin40-deficient mice. Curr Biol 1998;8:299-302.
65 Simon AM, McWhorter AR: Vascular abnormalities in mice lacking the endothelial gap junction proteins connexin 37 and connexin40. Dev Biol 2002;251:206-220.

66 de Wit C, Griffith TM: Connexins and gap junctions in the EDHF phenomenon and conducted vasomotor responses. Pflügers Arch 2010;459:897-914.

67 Haddock RE, Grayson TH, Brackenbury TD, Meaney KR, Neylon CB, Sandow SL, Hill CE: Endothelial coordination of cerebral vasomotion via myoendothelial gap junctions containing connexins 37 and 40. Am J Physiol Heart Circ Physiol 2006;291:H2047-H2056.

68 Chaytor AT, Marsh WL, Hutcheson IR, Griffith TM: Comparison of glycyrrhetinic acid isoforms and carbenoxolone as inhibitors of EDHF-type relaxations mediated via gap junctions. Endothelium 2000;7:265-278.

69 Chaytor AT, Martin PE, Edwards DH, Griffith TM: Gap junctional communication underpins EDHF-type relaxations evoked by ACh in the rat hepatic artery. Am J Physiol Heart Circ Physiol 2001;280:H2441-H2450.

-70 Chaytor AT, Bakker LM, Edwards DH, Griffith TM: Connexin-mimetic peptides dissociate electrotonic EDHF-type signalling via myoendothelial and smooth muscle gap junctions in the rabbit iliac artery. Br J Pharmacol 2005; 144:108-114.

71 Mather S, Dora KA, Sandow SL, Winter P, Garland CJ: Rapid endothelial cell-selective loading of connexin 40 antibody blocks endothelium-derived hyperpolarizing factor dilation in rat small mesenteric arteries. Circ Res 2005;97:399-407.

-72 de Wit C, Roos F, Bolz SS, Kirchhoff S, Kruger $\mathrm{O}$, Willecke K, Pohl U: Impaired conduction of vasodilation along arterioles in connexin 40-deficient mice. Circ Res 2000;86:649655 .

73 Figueroa XF, Paul DL, Simon AM, Goodenough DA, Day KH, Damon DN, Duling BR: Central role of connexin 40 in the propagation of electrically activated vasodilation in mouse cremasteric arterioles in vivo. Circ Res 2003; 92:793-800.

-74 Wolfle SE, Schmidt VJ, Hoepfl B, Gebert A, Alcolea S, Gros D, de Wit C: Connexin 45 cannot replace the function of connexin 40 in conducting endothelium-dependent dilations along arterioles. Circ Res 2007;101: 1292-1299.

75 Figueroa XF, Duling BR: Dissection of two Cx37-independent conducted vasodilator mechanisms by deletion of $\mathrm{Cx} 40$ : electrotonic versus regenerative conduction. Am J Physiol Heart Circ Physiol 2008;295:H2001-H2007.

76 Gabriels JE, Paul DL: Connexin 43 is highly localized to sites of disturbed flow in rat aortic endothelium but connexin 37 and connexin 40 are more uniformly distributed. Circ Res 1998;83:636-643. 
-77 Pfenniger A, Wong C, Sutter E, Cuhlmann S, Dunoyer-Geindre S, Mach F, Horrevoets AJ, Evans PC, Krams R, Kwak BR: Shear stress modulates the expression of the atheroprotective protein Cx37 in endothelial cells. J Mol Cell Cardiol 2012;53:299-309.

-78 Davies PF, Civelek M: Endoplasmic reticulum stress, redox, and a proinflammatory environment in athero-susceptible endothelium in vivo at sites of complex hemodynamic shear stress. Antioxid Redox Signal 2011;15: 1427-1432.

79 Chadjichristos CE, Scheckenbach KE, van Veen TA, Richani Sarieddine MZ, de Wit C, Yang Z, Roth I, Bacchetta M, Viswambharan H, Foglia B, Dudez T, van Kempen MJ, Coenjaerts FE, Miquerol L, Deutsch U, Jongsma HJ, Chanson M, Kwak BR: Endothelial-specific deletion of connexin 40 promotes atherosclerosis by increasing CD73-dependent leukocyte adhesion. Circulation 2010;121:123131.

80 Kwak BR, Veillard N, Pelli G, Mulhaupt F, James RW, Chanson M, Mach F: Reduced connexin43 expression inhibits atherosclerotic lesion formation in low-density lipoprotein receptor-deficient mice. Circulation 2003;107:1033-1039.

81 Ross R: Cell biology of atherosclerosis. Annu Rev Physiol 1995;57:791-804.

82 Meens MJ, Pfenniger A, Kwak BR, Delmar M: Regulation of cardiovascular connexins by mechanical forces and junctions. Cardiovasc Res 2013;99:304-314.

83 Yang Z, Ming XF: Recent advances in understanding endothelial dysfunction in atherosclerosis. Clin Med Res 2006;4:53-65.

-84 Pfenniger A, Derouette JP, Verma V, Lin X, Foglia B, Coombs W, Roth I, Satta N, Dunoyer-Geindre S, Sorgen P, Taffet S, Kwak BR, Delmar M: Gap junction protein Cx37 interacts with endothelial nitric oxide synthase in endothelial cells. Arterioscler Thromb Vasc Biol 2010;30:827-834.

85 Alonso F, Boittin FX, Beny JL, Haefliger JA: Loss of connexin 40 is associated with decreased endothelium-dependent relaxations and eNOS levels in the mouse aorta. Am J Physiol Heart Circ Physiol 2010;299:H1365H1373.

-86 Libby P, Ridker PM, Hansson GK: Inflammation in atherosclerosis: from pathophysiology to practice. J Am Coll Cardiol 2009;54:21292138.

-87 van Leeuwen M, Gijbels MJ, Duijvestijn A, Smook M, van de Gaar MJ, Heeringa P, de Winther MP, Tervaert JW: Accumulation of myeloperoxidase-positive neutrophils in atherosclerotic lesions in LDLR-/- mice. Arterioscler Thromb Vasc Biol 2008;28:84-89.

-88 Eugenin EA, Branes MC, Berman JW, Saez JC: TNF-alpha plus IFN-gamma induce connexin43 expression and formation of gap junctions between human monocytes/macrophages that enhance physiological responses. J Immunol 2003;170:1320-1328.
89 Leybaert L, Braet K, Vandamme W, Cabooter L, Martin PE, Evans WH: Connexin channels, connexin mimetic peptides and ATP release. Cell Commun Adhes 2003;10: 251-257.

\$0 Yuan D, Wang Q, Wu D, Yu M, Zhang S, Li L, Tao L, Harris AL: Monocyte-endothelial adhesion is modulated by $\mathrm{Cx} 43$-stimulated ATP release from monocytes. Biochem Biophys Res Commun 2012;420:536-541.

-91 Mendoza-Naranjo A, Bouma G, Pereda C, Ramirez M, Webb KF, Tittarelli A, Lopez MN, Kalergis AM, Thrasher AJ, Becker DL, Salazar-Onfray F: Functional gap junctions accumulate at the immunological synapse and contribute to $\mathrm{T}$ cell activation. J Immunol 2011;187:3121-3132.

92 Branes MC, Contreras JE, Saez JC: Activation of human polymorphonuclear cells induces formation of functional gap junctions and expression of connexins. Med Sci Monit 2002;8:BR313-BR323.

-93 Zahler S, Hoffmann A, Gloe T, Pohl U: Gapjunctional coupling between neutrophils and endothelial cells: a novel modulator of transendothelial migration. J Leukoc Biol 2003;73:118-126.

94 Jara PI, Boric MP, Saez JC: Leukocytes express connexin 43 after activation with lipopolysaccharide and appear to form gap junctions with endothelial cells after ischemiareperfusion. Proc Natl Acad Sci USA 1995; 92:7011-7015.

95 Sarieddine MZ, Scheckenbach KE, Foglia B, Maass K, Garcia I, Kwak BR, Chanson M: Connexin43 modulates neutrophil recruitment to the lung. J Cell Mol Med 2009;13: 4560-4570.

\$6 Eltzschig HK, Eckle T, Mager A, Kuper N, Karcher C, Weissmuller T, Boengler K, Schulz R, Robson SC, Colgan SP: ATP release from activated neutrophils occurs via connexin 43 and modulates adenosine-dependent endothelial cell function. Circ Res 2006;99:1100-1108.

-97 Kwak BR, Mulhaupt F, Veillard N, Gros DB, Mach F: Altered pattern of vascular connexin expression in atherosclerotic plaques. Arterioscler Thromb Vasc Biol 2002;22:225230.

$\$ 98$ van Rijen HV, van Kempen MJ, Postma S, Jongsma HJ: Tumour necrosis factor alpha alters the expression of connexin 43 , connexin 40 , and connexin37 in human umbilical vein endothelial cells. Cytokine 1998;10: 258-264.

$\$ 99$ Zernecke A, Bidzhekov K, Ozuyaman B, Fraemohs L, Liehn EA, Luscher-Firzlaff JM, Luscher B, Schrader J, Weber C: CD73/ecto$5^{\prime}$-nucleotidase protects against vascular inflammation and neointima formation. Circulation 2006;113:2120-2127.

100 Blackburn JP, Peters NS, Yeh HI, Rothery S, Green CR, Severs NJ: Upregulation of connexin43 gap junctions during early stages of human coronary atherosclerosis. Arterioscler Thromb Vasc Biol 1995;15:1219-1228.
01 Arishiro K, Hoshiga M, Ishihara T, Kondo $\mathrm{K}$, Hanafusa T: Connexin 43 expression is associated with vascular activation in human radial artery. Int J Cardiol 2010;145: 270-272.

102 Rennick RE, Connat JL, Burnstock G, Rothery S, Severs NJ, Green CR: Expression of connexin 43 gap junctions between cultured vascular smooth muscle cells is dependent upon phenotype. Cell Tissue Res 1993;271: 323-332.

103 Chadjichristos CE, Morel S, Derouette JP, Sutter E, Roth I, Brisset AC, Bochaton-Piallat ML, Kwak BR: Targeting connexin 43 prevents platelet-derived growth factor-BBinduced phenotypic change in porcine coronary artery smooth muscle cells. Circ Res 2008; 102:653-660.

104 Johnstone S, Isakson B, Locke D: Biological and biophysical properties of vascular connexin channels. Int Rev Cell Mol Biol 2009; 278:69-118.

105 Rama A, Matsushita T, Charolidi N, Rothery S, Dupont E, Severs NJ: Up-regulation of connexin 43 correlates with increased synthetic activity and enhanced contractile differentiation in TGF-beta-treated human aortic smooth muscle cells. Eur J Cell Biol 2006; 85:375-386.

106 Derouette JP, Wong C, Burnier L, Morel S, Sutter E, Galan K, Brisset AC, Roth I, Chadjichristos CE, Kwak BR: Molecular role of Cx37 in advanced atherosclerosis: a microarray study. Atherosclerosis 2009;206:69-76.

107 Polacek D, Lal R, Volin MV, Davies PF: Gap junctional communication between vascular cells: induction of connexin 43 messenger RNA in macrophage foam cells of atherosclerotic lesions. Am J Pathol 1993;142:593606.

108 Morel S, Sutter E, Roth I, Foglia B, Deutsch U, Theis M, Kwak BR: Endothelial-specific deletion of the gap junction proteinconnexin 43 reduces atherosclerosis in mice. Circulation 2008;118:S473.

109 Virmani R, Kolodgie FD, Burke AP, Farb A, Schwartz SM: Lessons from sudden coronary death: a comprehensive morphological classification scheme for atherosclerotic lesions. Arterioscler Thromb Vasc Biol 2000; 20:1262-1275.

110 Libby P: Molecular and cellular mechanisms of the thrombotic complications of atherosclerosis. J Lipid Res 2009;50(suppl):S352S357.

111 Angelillo-Scherrer A, Fontana P, Burnier L, Roth I, Sugamele R, Brisset A, Morel S, Nolli S, Sutter E, Chassot A, Capron C, Borgel D, Saller F, Chanson M, Kwak BR: Connexin 37 limits thrombus propensity by downregulating platelet reactivity. Circulation 2011;124: 930-939.

112 Vaiyapuri S, Moraes LA, Sage T, Ali MS, Lewis KR, Mahaut-Smith MP, Oviedo-Orta E, Simon AM, Gibbins JM: Connexin40 regulates platelet function. Nat Commun 2013; 4:2564. 
113 Vaiyapuri S, Jones CI, Sasikumar P, Moraes LA, Munger SJ, Wright JR, Ali MS, Sage T, Kaiser WJ, Tucker KL, Stain CJ, Bye AP, Jones S, Oviedo-Orta E, Simon AM, Mahaut-Smith MP, Gibbins JM: Gap junctions and connexin hemichannels underpin hemostasis and thrombosis. Circulation 2012; 125:2479-2491.

114 Dangas G, Kuepper F: Cardiology patient page. Restenosis: repeat narrowing of a coronary artery - prevention and treatment. Circulation 2002; 105:2586-2587.

- 115 Newsome LT, Kutcher MA, Royster RL: Coronary artery stents. 1 . Evolution of percutaneous coronary intervention. Anesth Analg 2008;107:552-569.

116 Matter CM, Ma L, von Lukowicz T, Meier P, Lohmann C, Zhang D, Kilic U, Hofmann E, Ha SW, Hersberger M, Hermann DM, Luscher TF: Increased balloon-induced inflammation, proliferation, and neointima formation in apolipoprotein $\mathrm{E}$ (ApoE) knockout mice. Stroke 2006;37: 2625-2632.
117 Chadjichristos CE, Matter CM, Roth I, Sutter E, Pelli G, Luscher TF, Chanson M, Kwak BR: Reduced connexin 43 expression limits neointima formation after balloon distension injury in hypercholesterolemic mice. Circulation 2006;113:2835-2843.

118 Yeh HI, Lupu F, Dupont E, Severs NJ: Upregulation of connexin43 gap junctions between smooth muscle cells after balloon catheter injury in the rat carotid artery. Arterioscler Thromb Vasc Biol 1997;17:31743184.

119 Bochaton-Piallat ML, Ropraz P, Gabbiani F, Gabbiani G: Phenotypic heterogeneity of rat arterial smooth muscle cell clones: implications for the development of experimental intimal thickening. Arterioscler Thromb Vasc Biol 1996;16:815-820.

120 Hao H, Ropraz P, Verin V, Camenzind E, Geinoz A, Pepper MS, Gabbiani G, Bochaton-Piallat ML: Heterogeneity of smooth muscle cell populations cultured from pig coronary artery. Arterioscler Thromb Vasc Biol 2002;22:1093-1099.
121 Song M, Yu X, Cui X, Zhu G, Zhao G, Chen J, Huang L: Blockade of connexin 43 hemichannels reduces neointima formation after vascular injury by inhibiting proliferation and phenotypic modulation of smooth muscle cells. Exp Biol Med (Maywood) 2009;234: 1192-1200.

122 Liao Y, Regan CP, Manabe I, Owens GK, Day KH, Damon DN, Duling BR: Smooth muscle-targeted knockout of connexin 43 enhances neointimal formation in response to vascular injury. Arterioscler Thromb Vasc Biol 2007;27:1037-1042.

123 Wang L, Chen J, Sun Y, Zhang F, Zhu J, Hu S, Wang DH: Regulation of connexin expression after balloon injury: possible mechanisms for antiproliferative effect of statins. Am J Hypertens 2005; 18:1146-1153.

124 Li DQ, Chen WX, Zhou YP, Han Y: Effect of ramipril on the regulation of the expression of connexins 40 and 43 in a rabbit model of arterial balloon injury. Mol Med Rep 2012;6: 565-569.

125 Matsuuchi L, Naus CC: Gap junction proteins on the move: connexins, the cytoskeleton and migration. Biochim Biophys Acta 2013;1828:94-108. 